\title{
TOWARDS MULTIFUNCTIONALITY OF MINING LANDSCAPES IN THE ESTONIAN OIL SHALE BASIN: TYPOLOGIES, ASSESSMENT AND PLANNING
}

\author{
K. $\operatorname{SEPP}^{(\mathrm{a})}, \mathrm{A} \cdot \mathrm{ROOSE}^{(\mathrm{b})^{*}}$ \\ (a) Institute of Agricultural and Environmental Sciences \\ Estonian University of Life Sciences \\ Kreutzwaldi 1, 51014 Tartu, Estonia \\ (b) Department of Geography, University of Tartu \\ Vanemuise 46, 51014 Tartu, Estonia
}

\begin{abstract}
The paper introduces the landscape assessment approach for the post-mining landscapes in the Estonian oil shale open-cast mines. Typologies of mining landscapes are based on landscape pattern, features and functions predetermined by mining technologies. The open-cast mines which have been predominantly subjected to monofunctional reforestation should direct to diversification of landscape and its functions to enrich biodiversity and public uses. Despite controversial approaches and image on mining landscapes reasons for higher appraisal and multifunctional use of mining areas are argued. Preserving heritage-valued mining landscapes could be applied using integrated physical planning.
\end{abstract}

\section{Introduction}

In recent years, more focus has been given to the mitigating role of landscapes in the case of human impact [1]. The idea of incorporating into physical planning of mining landscapes is mutually originated from landscape science and landscape ecology principles along with various social functions such as multifunctional cultural and recreational landscapes [2-4]. Though, the reclamation of the open-cast mines with the main focus on landscape planning, design and ecology carried out in the northeastern part of Estonia hitherto number but a few. The legislation prescribes reclamation of land for the intended purpose and land use indicated in the mining permit. Although the Estonian regulation and norms for reclamation of extracted areas are based on legal principles and are utterly uncompromised in terms of engineering, they do not follow landscape approach much. Ecological,

\footnotetext{
* Corresponding author: e-mail antti.roose@ut.ee
} 
socio-cultural and economic benefits of mixed uses are often not fully taken into account, and multifunctional landscapes continue to be rare exception. In addition, the post-modernist discourse of physical planning criticises zoning with regard to land use that leads to the 'stratification' of landscapes, a multitude of monofunctional areas, and conflicts between various zonings [5].

In the context of progressing landscape concept in reclamation of the Estonian oil shale open-cast mines, the paper aims to refine landscape typology of mining areas, to assess their ecological functions and values. The framework presented in this paper facilitates the structured assessment of the goods and services provided by a post-mining landscapes.

\section{Methods and materials}

Consequences of variations in the landscapes evolve structural heterogeneity and functional heterogeneity. In essence, all landscapes are multifunctional per definition [6]. In order to reconcile mining and landscape conservation with changing demands on land use and natural resources, it is essential that the ecological, socio-cultural and economic values of the landscape be fully taken into account in planning. Though, it is still difficult to express the importance of the functions of landscapes in monetary terms because most of the benefits are not captured in conventional economic analysis [7].

The modelling approach employed here involves historical approach, landscape structures, and landscape functions [8]. Setting generic typology for mining and post-mining landscapes is based first on bio-geophysical domain related to physical, biological and chemical processes. Second, it recognizes landscape functions (cultural, regulating, provisioning, recreational), third socio-economic uses (urban, rural areas). In addition to the main landscape biotic, physiography and socio-economic characteristics of mining landscapes are judged by their pattern and structure. In the case of mining landscapes, there are good reasons to represent landscape on the basis of its formal geometry and the density of linear features. As landscape and its change is often comprehended through land cover, it is used for delineating and distinguishing mining landscapes. Landscape naturalness as a conceptual framework is assessed according to the complement of native species that habit in a mining-disturbed area and reclamated area compared with those present prior to mining intervention [9]. Post-mining landscapes are examined and assessed according to functions, values and potential uses.

In analysis of ecosystem and landscape functions the methodological approach of de Groot [7] was upgraded and applied at a case study in the Estonian oil shale basin. The first step in the analysis involves the translation of ecological complexity (structures and processes) into a more limited number of landscape functions. These functions, in turn, provide the goods and services that are valued by humans. In this paper, ecosystem functions 
are defined by de Groot [7] as the capacity of natural processes and components to provide goods and services that satisfy human needs, directly or indirectly. In this assessment exercise, ecosystem functions are grouped into four primary categories and their ecological, economic and sociocultural values are evaluated. Functions are structured as follows: regulation functions, habitat functions, production functions, information functions, and carrier functions. Functions of major mining landscapes types, plus prospective multifunctional landscape were evaluated by expert pool of geographers and ecologists using robust qualitative scale poor-satisfactorygood.

The following digital maps and spatial databases served as a basis for landscape analysis in this study: Estonian base map (1:50 000 vector map, Estonian Land Board), Estonian CORINE land cover map of Estonia (1:100 000 vector map, Ministry of Environment), landscape map outlining meso-scale landscape units' subtypes (1:50 000 vector map) [10], land use map (1:10 000 cadastral raster map, Estonian Land Board), maps of mining fields (Eesti Energia Kaevandused Ltd; The Mining Institute, Tallinn University of Technology), Soviet military topographic map (1:50 000), maps of physical and master planning, orienteering and project-oriented maps of mining areas (up to 1:5000).

\section{Results}

\section{Setting landscape typology for oil shale mining landscapes}

There have been several attempts at embracing mining landscapes into typologies of Estonian natural landscapes. Arold [10] subdivided mining areas at Viru plateau in northeastern Estonia as a place of a technogenic group of hills. Similarly, earlier landscape typologies originating from relief and interrupted processes faced difficulties in distinguishing the industrial landscapes of northeastern Estonia and providing a methodical insight into their merits by landscape sciences. Kildema [11] proposed a concept of industrial North. Varep [12] stressed on the significant landscape changes due to oil shale mining in the plateau of northeastern Estonia, Jõhvi upland as well as Alutaguse, by treating these areas as typical industrial landscapes. The difference is not well revealed in the types of land use either, since the area of changed and reclamated land has been more or less balanced over the last decades, being up to 180 ha in the recent years [13]. Reclamated landscapes are defined as technogenic hills with a well-structured physiography [10]. Landscape researchers would be intrigued by a proposal to outline spatially the eastern open-cast mines, Narva, Sirgala and Viivikonna with a total area of $300 \mathrm{~km}^{2}$ as a distinguished landscape district in the pattern of Estonian landscapes. Also, the landscape units may be defined on the basis of reclamation scheme used, the age of open-cast mines and physical form of land surface. Open-cast mines, their technological processes set the 
structural component, skeleton of the landscape to be reclamated. On the basis of landscape features, development history, mining origins, and postmining land use, the mining landscapes can be grouped as follows (Table 1):

- 'Old' open-cast mines;

- 'New' open-cast mines;

- Heaps of mining residues;

- Industrial estates (for serving operations of mines, mineyards).

Table 1. Key features of mining landscape types of the Estonian oil shale district

\begin{tabular}{|c|c|c|c|c|c|c|c|c|}
\hline 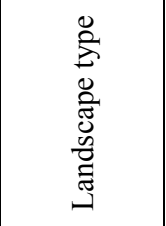 & 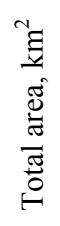 & 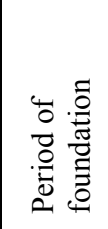 & 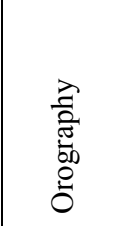 & 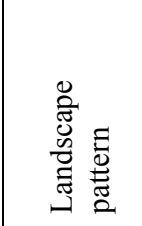 & 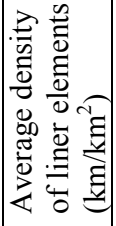 & 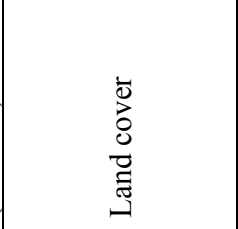 & 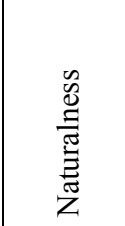 & 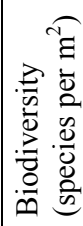 \\
\hline $\begin{array}{l}\text { 'Old' open- } \\
\text { cast mines }\end{array}$ & 6 & $\begin{array}{l}1920 \mathrm{~s}- \\
1950 \mathrm{~s}\end{array}$ & $\begin{array}{l}\text { Hilly, } \\
\text { steep } \\
\text { slopes }\end{array}$ & $\begin{array}{l}\text { Hetero- } \\
\text { geneous }\end{array}$ & $9-11$ & $\begin{array}{l}\text { Coniferous forest } \\
\text { Mixed forest } \\
\text { Woodland scrub }\end{array}$ & Medium & $<50$ \\
\hline $\begin{array}{l}\text { open-cast } \\
\text { mines }\end{array}$ & 124 & $\begin{array}{l}1960 \mathrm{~s}- \\
\text { present }\end{array}$ & $\begin{array}{l}\text { Wavy } \\
\text { plateaus } \\
\text { with } \\
\text { valleys }\end{array}$ & $\begin{array}{l}\text { Mono- } \\
\text { tonous, } \\
\text { large } \\
\text { planned } \\
\text { structures }\end{array}$ & $3-4$ & $\begin{array}{l}\text { Coniferous forest } \\
\text { Mixed forest } \\
\text { Agricultural areas } \\
(169 \text { ha }) \\
\text { Bare rock } \\
\text { Water bodies } \\
(15 \text { ha })\end{array}$ & $\begin{array}{l}\text { Medium- } \\
\text { low }\end{array}$ & $<35$ \\
\hline $\begin{array}{l}\text { Heaps of } \\
\text { mining } \\
\text { residues } \\
\text { (limestone) }\end{array}$ & 3 & $\begin{array}{l}\text { 1940s- } \\
\text { present }\end{array}$ & $\begin{array}{l}\text { Hills, } \\
\text { steep } \\
\text { slopes }\end{array}$ & $\begin{array}{l}\text { Homo- } \\
\text { geneous, } \\
\text { geometric } \\
\text { layout }\end{array}$ & $8-20$ & $\begin{array}{l}\text { Bare rock } \\
\text { Coniferous forest } \\
\text { Woodland scrub }\end{array}$ & Low & 10 \\
\hline $\begin{array}{l}\text { Industrial } \\
\text { estates (for } \\
\text { serving } \\
\text { operations } \\
\text { of mines, } \\
\text { mineyards) }\end{array}$ & 10 & $\begin{array}{l}1920 \mathrm{~s}- \\
\text { present }\end{array}$ & $\begin{array}{l}\text { Flat, } \\
\text { small } \\
\text { hills }\end{array}$ & $\begin{array}{l}\text { Geometric } \\
\text { forms, } \\
\text { mosaic }\end{array}$ & $20-30$ & $\begin{array}{l}\text { Industrial } \\
\text { Discontinuous } \\
\text { urban fabric } \\
\text { Bare rock }\end{array}$ & Low & \begin{tabular}{|l|} 
Not \\
valid
\end{tabular} \\
\hline
\end{tabular}

The 'old' oil shale mines, operated mainly before World War II as well as in the 1940s-1950s in Vanamõisa, Küttejõu, Kohtla and Viivikonna [14, 15], have undergone a natural succession and, hence, served as a good reference area for comparison with reclamated areas. Presently, older open-cast mines are located in urban areas or adjoin densely populated built environment. No levelling works have been performed in older open-cast mines, the areas with an edged relief and a small pattern are covered with forests. The main form of the landscape having dense linear network $\left(9-11 \mathrm{~km} / \mathrm{km}^{2}\right)$ has been rendered by relatively densely situated trenches dredged like a fishtail attractively presented in Küttejõu and Kohtla. Spontaneous reforestation has 
led to a forest stand with a substantially larger number of species that will also add much to the visual appearance and aesthetical values of the landscape. As a result of natural regeneration, today the areas are mostly covered with coniferous forest with the number of species of up to 50 species per $\mathrm{m}^{2}$ [16].

The transition line between 'old' and 'new' lays in the late 1950s. Since the 1960s, oil shale mines have been reforested in a regular planned manner, but up to 1968, mines were only partially levelled and landscaped [13]. The typical post-mining landscape is shaped by tetragonous plain or undulating plateaus with an average size of $2000 \times 1000$ metres and relative altitude rangeing 10-30 metres, separated by trenches $[17,18]$. The density of linear elements is rather low, up to $4 \mathrm{~km} / \mathrm{km}^{2}$. The pine forests $\left(\mathrm{ca} 100 \mathrm{~km}^{2}\right.$, other forests $20 \mathrm{~km}^{2}$ ) have been predominant, agricultural land reclamated from mining in Aidu covers just $1.69 \mathrm{~km}^{2}$ [13]. The pine stands, demonstrating success in terms of forest management, are not the richest in terms of landscape and biological diversity. The diversity of a post-mining landscape declines as compared with the pre-mining natural landscape whilst the structure of the relief and the ranges of altitude increase remarkably. The morphological characteristics of a landscape upon reclamation become a key issue in relation to reshaping the relief and need to ensure the physical stability of the new landforms and safety of post-mining land use.

Heaps of mining residues, mainly limestone (in the neighbourhood of mine yards, $300 \mathrm{ha}$ ) are depositories of mining waste, basically consisting of limestone with an irregular shape, a width of 130-360 m and height of $15-55 \mathrm{~m}$ in the vicinity of processing and enrichment plants. Older hills of mining waste that, as a rule, self-ignited in the 1960s have a conical shape [18]. The hills of mining waste of later origin in the mines of Tammiku, Ahtme, Viru and Estonia were designed as flat heaps and were heightened as terraces to avoid the risk of self-ignition. Lately, these heaps have been constantly reshaped and lowered due to increased demand and processing of limestone gravel.

The industrial estates for serving operations of mines, including the mining yards and other surface infrastructure, cover a considerable area, $11.8 \mathrm{~km}^{2}$. A landscaping of mining yards and physical planning of industrial estates started in the 1960s. The mineyards of Sompa, Tammiku and Ahtme that were closed down in 1999 are basically used by small enterprises as works and warehouses. The Kohtla mineyard is developed as the mining museum-park exhibiting integrity and history of this architectural ensemble.

\section{Preserving industrial heritage}

For landscape preservation and conservation, one must decide whether there is an intention to preserve also the processes and functions that have provided the landscape, or there is a need to preserve a certain condition, i.e. physical and visual appearance of the landscape [19, 20]. Heritage has often been defined as objects and sites of historic interest, but today the definition 
is much broader and encompasses entire landscapes, saleable commodities (i.e. tourist attractions), and inhabitant perceptions [21]. Mining landscapes and industrial complexes were, unlike never before, valued as objects of cultural value of global significance. In 1972 UNESCO adopted the Convention Concerning the Protection of the World Cultural and Natural Heritage. The almost 700 objects of cultural heritage in the list of world heritage include nearly 20 industrial landscapes, most of them mining districts and settlements - the first ones, for example, were the salt mine of Wieliczka in Poland in 1978 and the mining town of Røros in Norway in 1980. In Estonia, just 35 out of the 25607 cultural heritage monuments are listed and preserved as technology/engineering heritage [22]. To admit, the 1491 listed heritages of Ida-Virumaa do not include as single engineering site. Notionally the buildings of Kreenholm in Narva could be regarded as industrial heritage such. For the Estonian oil shale mining and industrial landscapes, it is highly relevant to preserve the dominant elements in the landscape image, in this example, hills of mining waste, landmark premises, mining towers and facilities. Only the administrative building (built in 1946-48) of the Sompa mine that has been taken under heritage conservation in 1997 has not ensured the preservation. In addition, derelict mines (Kukruse, Käva, mine no 2, mine no 4 and Kiviõli) are marked with memorial stones. Hills of mining waste nearby are symbolic landmarks. Mining facilities and infrastructure preserved are few, and a former mining yard can be seen as an integral architectural ensemble only in Kohtla.

\section{Assessment of landscape functions for diversification}

The comparative assessment of mining landscapes integrates 17 relevant functions of four segments and three values (Table 2). The information and carrier function are poor in 'old' open-cast mines. The information function is marked higher than satisfactory in industrial estates, staying below the satisfactory level in heaps of mining residues. The regulation function is assessed higher in old and new mining areas than in heaps or mineyards. The assessment reveals that all functions in all landscape types range between poor and satisfactory compared to the prospective multifunctional mining landscape where all functions except regulation function are marked as good. Comparing values of former mining areas, the socio-cultural and economic value could be increased substantially in multifunctional reclamation of mining areas.

Landscape reclamation of open-cast mines and assigning new functions to the post-mining areas has been actively discussed and briskly debated in Estonia for decades. In the 1960s and 1970s, Kaar, Luik, Niine [23-25] and others published research articles, agendas and manuals for landscape development, though there were a few enthusiasts who practiced the landscape approach in reclamation. Usually different combinations of land uses are possible. A focal point of landscape management at post-mining areas should be improving of the value of the landscape. In practice, the landscape 
Table 2. Assessment of functions and values of mining landscapes

\begin{tabular}{|c|c|c|c|c|c|}
\hline $\begin{array}{l}\text { Functions and values of mining } \\
\text { landscapes }\end{array}$ & 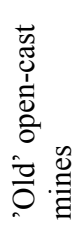 & 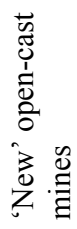 & 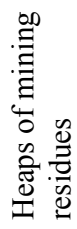 & 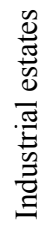 & 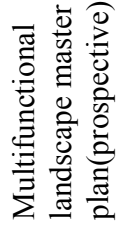 \\
\hline Regulation functions & 1.5 & 1.5 & 1 & 1 & 2 \\
\hline $\begin{array}{l}\text { Soil formation } \\
\text { Gas regulation }\end{array}$ & $\begin{array}{l}1 \\
2\end{array}$ & $\begin{array}{l}1 \\
2\end{array}$ & $\begin{array}{l}1 \\
1\end{array}$ & $\begin{array}{l}1 \\
1\end{array}$ & $\begin{array}{l}2 \\
2\end{array}$ \\
\hline Habitat functions & 1.2 & 1.4 & 1.4 & 1.4 & 3 \\
\hline $\begin{array}{l}\text { Refugium function } \\
\text { Nursery function } \\
\text { Food } \\
\text { Raw materials } \\
\text { Ornamental resources }\end{array}$ & $\begin{array}{l}1 \\
1 \\
2 \\
1 \\
1\end{array}$ & $\begin{array}{l}1 \\
1 \\
2 \\
2 \\
1\end{array}$ & $\begin{array}{l}1 \\
1 \\
1 \\
2 \\
2\end{array}$ & $\begin{array}{l}1 \\
1 \\
1 \\
1 \\
3\end{array}$ & $\begin{array}{l}3 \\
3 \\
3 \\
3 \\
3\end{array}$ \\
\hline Information functions & 1.4 & 1.2 & 1.8 & 2.4 & 3 \\
\hline $\begin{array}{l}\text { Aesthetic information } \\
\text { Recreation } \\
\text { Cultural and artistic information } \\
\text { Spiritual and historic information } \\
\text { Science and education }\end{array}$ & $\begin{array}{l}1 \\
2 \\
1 \\
1 \\
2\end{array}$ & $\begin{array}{l}1 \\
1 \\
1 \\
1 \\
2\end{array}$ & $\begin{array}{l}2 \\
2 \\
1 \\
2 \\
2\end{array}$ & $\begin{array}{l}2 \\
3 \\
2 \\
3 \\
2\end{array}$ & $\begin{array}{l}3 \\
3 \\
3 \\
3 \\
3\end{array}$ \\
\hline Carrier functions & 1 & 1.2 & 1.6 & 1.4 & 2.6 \\
\hline $\begin{array}{l}\text { Habitation } \\
\text { Cultivation } \\
\text { Energy-conversion } \\
\text { Mining } \\
\text { Tourism facilities }\end{array}$ & $\begin{array}{l}1 \\
1 \\
1 \\
1 \\
1\end{array}$ & $\begin{array}{l}1 \\
2 \\
1 \\
1 \\
1\end{array}$ & $\begin{array}{l}1 \\
1 \\
2 \\
2 \\
2\end{array}$ & $\begin{array}{l}1 \\
1 \\
1 \\
1 \\
3\end{array}$ & $\begin{array}{l}3 \\
2 \\
3 \\
2 \\
3\end{array}$ \\
\hline $\begin{array}{l}\text { Ecological value } \\
\text { Socio-cultural value } \\
\text { Economic value }\end{array}$ & 1 & $\begin{array}{l}2 \\
1 \\
1\end{array}$ & $\begin{array}{l}1 \\
2 \\
2\end{array}$ & $\begin{array}{l}1 \\
3 \\
2\end{array}$ & $\begin{array}{l}2 \\
3 \\
3\end{array}$ \\
\hline
\end{tabular}

value could be raised by mixed stands at 'new' mines that upon alternating ecotopes contribute an edge effect for increasing biological as well as landscape diversity. The former mining areas, all types 'old' and 'new' open-cast mines, heaps of residues as well former mineyards would be areas for recreation, parks, hiking, theme parks, for military and industrial uses. The multi-functional post-mining re-use is featured the best in the mining museum of Kohtla which is the model case what can be done with a derelict mine and its territory and facilities [26]. Among other recreational landscapes, the urban park in Kohtla-Järve at the territory of Pavandu open-cast mine provides a diverse recreation zone for families and children. The heap of mining waste of Kukruse, one of the most popular tourist sites in IdaVirumaa, offers an emblematic panorama of the silhouette of oil shale landscapes. In non-urban areas, the military character of the landscapes is underpinned as the landscapes of Sirgala have been used for military training. The Ministry of Defence has proposed to construct a military training field $\left(28 \mathrm{~km}^{2}\right)$ for defence forces in the post-mining state forests of Sirgala along with an area for long-distance firearms and tactical exercises $\left(64 \mathrm{~km}^{2}\right)$ [27]. 


\section{Conclusions and recommendations}

The paper indicates the reason for higher appraisal of mining areas and stresses on the need to preserve mining landscapes exemplified by best practices multifunctional use of post-mining landscapes. Landscape scale is essential in any biodiversity protection as well for multifunctional uses. Considering the methods applied in reclamation along the principle of reclamation of large areas of open-cast mines, the Estonian oil shale opencast mines are predominantly subjected to monofunctional reclamation projects, reforestation along with strictly necessary hydro-technical and infrastructural facilities. Consequently, the reclamation standards should be supplemented by stronger criteria of landscape and biological diversity. The landscape assessment of the Estonian oil-shale mining areas explored that ecological functions as well landscape values will be substantially increased in the case of mixed uses of landscapes. Presently, multifunctional post-mining areas are designated more on recreational functions as well there is a tendency for military use of mining areas in the northeastern Estonia.

The criticism of the physical, landscape planning practice, applied concerns, on the one hand, the prevention of post-mining impacts, and, on the other hand, longer-term integrated strategic planning [13,28]. The physical planning should cover an area, larger than just one mining division to be closed. A larger area makes it possible to diversify post-mining landscapes with master planning and using landscape architecture in a more integral way, by defining various functions, diversity, ecological networks and integrity, functional contrasts feasible to the given artificial landscape forms and elements. For the complete derelict areas, a thematic general plan should be drafted, debated publicly and issued jointly by authorities. For the future, it depends on mining technology and innovation for meeting more demanding environmental and economic requirements. Finally, mining landscapes should embrace a positive, innovative place and unique representation in the identity of northeastern part of Estonia, Ida-Virumaa.

\section{Acknowledgements}

This study is supported by Estonian Target Funding Project SF1090050s07 and SF0180052s07, Grant ETF7459 of the Estonian Science Foundation, Environmental Investment Centre and the company "Eesti Energia Kaevandused". 


\section{REFERENCES}

1. Goldman, R., Thompson, B., Daily, G. Institutional incentives for managing the landscape: Inducing cooperation for the production of ecosystem services // Ecol. Econ. 2007. Vol. 64, No. 2. P. 333-343.

2. Ahern, J. Spatial concepts, planning strategies and future scenarios: a framework method for integrating landscape ecology and landscape planning // Landscape Ecological Analysis: Issues and Applications / J. Klopatec, R. Gardner (eds.). New York: Springler-Verlag, 1999. P. 175-201.

3. Hands, D. E., Brown, R.D. Enhancing visual preference of ecological rehabilitation Sites // Landscape Urban Plan. 2002. Vol. 58, No. 1. P. 57-70.

4. Nassauer, J. I. Culture and changing landscape structure//Landscape Ecol. 1995. Vol. 10, No. 4. P. 229-237.

5. Gospodini, A. Portraying, classifying and understanding the emerging landscapes in the post-industrial city // Cities. 2006. Vol. 23, No. 5. P. 311-330.

6. Forman, R. T. T., Gordon, M. Landscape Ecology. - New York: John Wiley and Sons, 1986.

7. de Groot, R. S. Function-analysis and valuation as a tool to assess land use conflicts in planning for sustainable, multi-functional landscapes // Landscape Urban Plan. 2006. Vol. 75, No. 3-4. P. 175-186.

8. Vogt, P., Riitters, K. H., Kozak, J., Soille, P. Mapping landscape corridors // Ecol. Indic. 2007. Vol. 7, No. 2. P. 481-488.Allik, A. (ed). 50 Years of Oil Shale Mining in Estonian SSR. - Tallinn: Valgus, 1968 [in Estonian].

9. Farina, A. Principles and Methods in Landscape Ecology. - London: Chapman \& Hall, 1998.

10. Arold, I. Estonian Landscapes. - Tartu: Tartu University Press, 2005 [in Estonian].

11. Kildema, $K$. On landscape partition in Estonian SSR// Designing Landscapes in Estonian SSR / M. Margus (ed). Tallinn: Valgus, 1969. P. 5-15 [in Estonian].

12. Varep, E. Landscapes// Kohtla-Järve District/V. Tarmisto (ed.). Tallinn: Academy of Sciences, 1983. P. 61-74 [in Estonian].

13. National Development Plan of Oil Shale Use 2008-2015. - Tallinn: Ministry of Environment, 2008 [in Estonian].

14. Allik, A. (ed). 50 Years of Oil Shale Mining in Estonian SSR. - Tallinn: Valgus, 1968 [in Estonian].

15. Kattai, V., Saadre, T., Savitski, L. Estonian Oil Shale, Geology, Resource, Mining Conditions. - Tallinn: Eesti Geoloogiakeskus (Geological Survey of Estonia), 2000 [in Estonian].

16. Karu, H., Luud, A., Pensa, M., Rull, E., Vaht, R. On vegetation succession in recultivation of oil shale mines // Environment and Oil Shale Mining in Northeastern Estonia / V. Liblik, J.-M. Punning (eds.). Tallinn: Institute of Ecology of Tallinn University, 2005. P. 121-133 [in Estonian].

17. Reinsalu, E., Toomik, A., Valgma, I. Mined-Out Land. - Tallinn: Mining Institute of Tallinn University of Technology, 2002 [in Estonian].

18. Toomik, A. Environmental heritage of oil shale mining// Oil Shale. 1998. Vol. 15, No. 2. P. 170-183.

19. Palang, H., Sepp, K., Sooväli, H. Estonian landscape heritage and its preservation options // Estonia in Its Sustainable Development Track/J.-M. Punning (ed). Tallinn: Eesti Entsüklopeediakirjastus, 2006. P. 75-83 [in Estonian]. 
20. Parts, P.-K. Towards the technology of cultural production: case of cultural heritage // Akadeemia. 2007. No. 2. P. 227-271 [in Estonian].

21. Ashworth, G. J., Larkham, P.J. A Heritage for Europe// Building a New Heritage / G. J. Ashworth, P. J. Larkham (eds.). London: Routledge, 1994. P. 1-9.

22. Muinsuskaitseamet (National Heritage Board), http://www.muinas.ee/413 accessed 20.10.2008 [in Estonian].

23. Kaar, E., Lainoja, L., Luik, H., Raid, L. Vaus, M. Recultivation of Opencast Mines. - Tallinn: Valgus, 1971 [in Estonian].

24. Luik, $H$. On nature conservation in northeastern Estonia// Eesti Loodus (Estonian Nature). 1966. No. 2. P. 89-95 [in Estonian].

25. Niine, A. Designing approaches of industrial landscape in the oil shale basin of northeastern Estonia// Landscape Design in Estonian SSR / M. Margus (ed). Tallinn: Valgus, 1969. P. 20-32 [in Estonian].

26. Tomberg, E. Use of oil shale mining areas // Mining Improves Land / E. Reinsalu (ed.). Tallinn: Tallinn University of Technology, 2007. P. 37-38 [in Estonian].

27. Riige, S. (ed.). Zoning and Usage Conditions of Sirgala Military Exercise Field. - Tallinn: AS Maves, contract 5228, 2006 [in Estonian].

28. Ida-Viru County Plan's Thematic Plan on Oil Shale Mining Areas. - Jõhvi, 2002 [in Estonian].

Presented by E. Reinsalu

Received January 23, 2009 